\title{
Influence of temperature and cheatgrass competition on seedling development of two bunchgrasses
}

\author{
LUCRECIA AGUIRRE AND DOUGLAS A. JOHNSON
}

\begin{abstract}
Rapid seedling growth and ability to compete against cheatgrass (Bromus tectorum L.) are 2 characteristics that perennial grasses must have for successful establishment on semiarid western rangelands. This study was conducted to determine the effects of temperature and competition from cheatgrass on seedling root and shoot growth of 'Hycrest' crested wheatgrass [A gropyron desertorum (Fisch. ex Link) Schult. $\times A$. cristatum (L.) Gaert.] and 'Whitmar' bluebunch wheatgrass ( Pseudoroegneria spicata (Pursh) Löve]. For the temperature study, seedlings were grown in growth chambers with alternate 12-h day/night temperatures of $10 / 5$, $15 / 5$, and $20 / 5^{\circ}$ C. Seedlings were destructively harvested on 6 dates and evaluated for 14 root and shoot characteristics. Leaf development, leaf area, total root length, and number and length of the second group of seminal roots were greater $(P<0.05)$ for cheatgrass than Hycrest and Whitmar at all dates and temperatures. Cheatgrass elongated adventitious roots earlier and at colder temperatures $\left(10 / 5^{\circ} \mathrm{C}\right)$ than Hycrest, and Whitmar did not produce adventitious roots at low temperatures. This would favor the establishment of cheatgrass at low temperatures. For the competition study, seedlings were established in pots in a greenhouse with planting ratios of Hycrest to cheatgrass and Whitmar to cheatgrass of 1:0, 2:0, and 5:0 $\left(32,64\right.$, and 159 plants $\mathrm{m}^{-2}$, respectively) and compared with planting ratios of $1: 1$ and 1:4. Fourteen shoot and root characteristics were evaluated 15,30 , and 50 days after seedling emergence. Hycrest had greater shoot and root development than Whitmar for all seedling characteristics. Competition from cheatgrass reduced growth of Hycrest and Whitmar seedlings. At a planting ratio of 1:4, Hycrest-cheatgrass mixtures depleted soil moisture to lower soil water potentials than Whitmar-cheatgrass mixtures. These results indicate that Hycrest seedlings are more effective competitors with cheatgrass than Whitmar seedlings.
\end{abstract}

Key Words: Hycrest, crested wheatgrass, A gropyron desertorum $X A$. cristatum, bluebunch wheatgrass, Pseudoroegneria spicata, cheatgrass, downy brome, Bromus tectorum, seedling establishment, root morphology

Bluebunch wheatgrass [Pseudoroegneria spicata (Pursh) Löve] is a perennial bunchgrass that is native to western North America. It was a dominant species in the Intermountain Region of the United States; however, the distribution and dominance of bluebunch wheatgrass have been reduced, and it has been almost eliminated in some areas by its susceptibility to grazing and extensive invasion by cheatgrass (Bromus tectorum L.) (Daubenmire 1942, Harris 1967, Caldwell et al. 1981). Cheatgrass is an introduced species from Eurasia (Klomp and Hull 1972), and its seeds germinate in the fall or early spring over a wide range of moisture and temperature conditions (Thill et al. 1979). Despite its wide distribution, competitive growth, and forage production (Young et al. 1987), cheatgrass has many undesirable characteristics including: a short growth period, marked yearly fluctuation in forage production, and a high fire hazard (Klomp and Hull 1972).

\footnotetext{
Authors are former research assistant, Dept. Range Science, Utah State University, Logan 84322-5230; plant physiologist, USDA-ARS, Forage and Range Research, Utah State University, Logan 84322-6300. Reprint requests should be sent to D.A Johnson.

Cooperative investigations of the USDA-ARS and the Utah Agricultural Experiment Station. Journal Paper 4010.

Manuscript accepted 10 December 1990.
}

Seedings of perennial grasses often fail because of the competitive ability of cheatgrass. Evans et al. (1970) proposed using a perennial grass species with vigorous seedling growth to overcome the competitive ability of cheatgrass. 'Hycrest' is a cultivar of hybrid crested wheatgrass [Agropyron cristatum (L.) Gaert. $\times A$. desertorum (Fisch. ex Link) Schult.] that may be able to successfully compete against cheatgrass (Asay et al. 1985). Hycrest is a palatable forage that has rapid root development and excellent seedling vigor, produces $20 \%$ more seed, and is more robust than either of the 2 parent species (Asay et al. 1985). In addition, Hycrest has temperature requirements for germination similar to those for cheatgrass (Buman and Abernethy 1988).

Range plants compete for light, water, and nutrients and have morphological, physiological, and phenological adaptations that enable them to persist in their environment (Harris 1967). Belowground competition in plants may be more important than aboveground competition (Snaydon and Howe 1986, King 1971). Roots of plants differ in the speed and efficiency in which they deplete soil resources (Tillman 1982). Generally, morphological characteristics of the root influence nutrient and water uptake rates more than physiological absorption capacities of the root (Clarkson 1985). Results of Johnson and Aguirre (1991) showed that root morphological development of 3 range grasses was influenced by water application and that the ability of cheatgrass seedlings to grow with little water was related to their order of branching of seminal roots, branching density on the main axis, and length of lateral roots and external-external links. Consequently, rooting characteristics are important for competitive effectiveness in range plants.

Root initiation and root growth rates usually increase with soil moisture and nutrient availability when temperatures are adequate for root growth (Barber 1984). Although grasses vary in their optimum temperature for root and shoot growth (Rosenquist and Gates 1961, Harris 1967), temperatures for optimum root growth are generally lower than temperatures for optimum shoot growth (Daubenmire 1942). Rapid seedling root growth at low temperatures may be important in arid environments because more moisture is generally available in the cool, early spring than in the hot, dry summer (Ellern and Tadmor 1967, Keller and Bleak 1969, Wilson et al. 1974). Consequently, the sooner roots penetrate the soil, the greater the probability of successful establishment. As a result, rapid root penetration at low temperatures may be essential in successfully establishing perennial grasses such as bluebunch wheatgrass or crested wheatgrass where the winter annual cheatgrass is abundant (DeWitt 1969).

The objective of this study was to determine the influence of temperature and cheatgrass competition at 3 planting densities on seedling root and shoot development in Hycrest and 'Whitmar' (a cultivar of bluebunch wheatgrass).

\section{Materials and Methods}

Seeds of Hycrest, Whitmar, and cheatgrass (obtained from a site near Pullman, Wash.) were used for both studies. Plastic pots (20 $\mathrm{cm} \times 20 \mathrm{~cm}$ ) were filled with $8 \mathrm{~kg}$ of a Kidman fine sandy loam (coarse-loamy mixed mesic Calcic Haploxeroll) series previously steamed for $4 \mathrm{~h}$. Seeds were germinated on moistened blotter paper at $25^{\circ} \mathrm{C}$ with a 12 -h photoperiod. When the primary root reached 2 

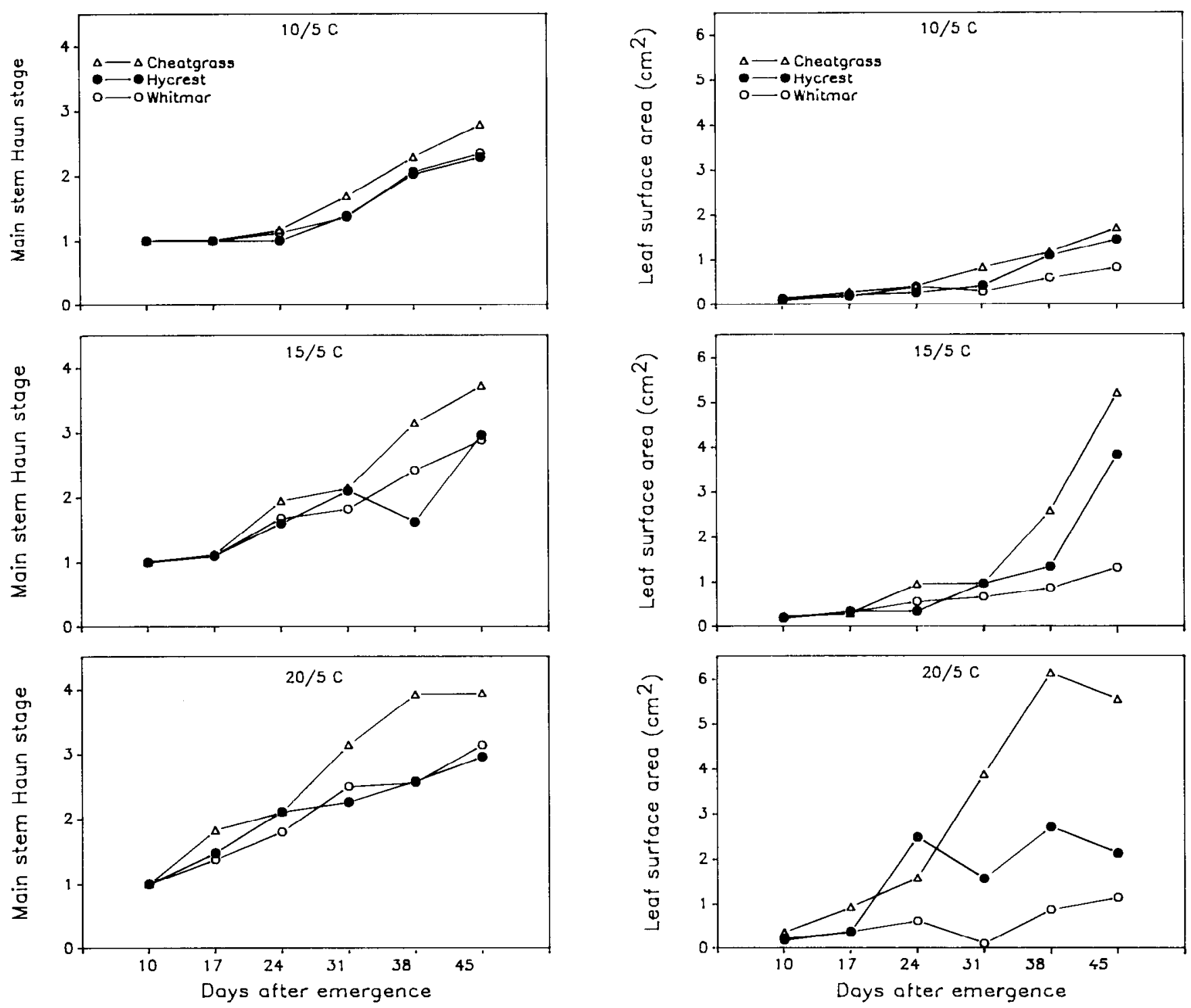

Fig. 1. Main stem Haun stage $(\mathrm{SD}=0.16)$ and leaf surface area $(\mathrm{SD}=\mathbf{0 . 6 4})$ for cheatgrass, Hycrest, and Whitmar as a function of days after emergence at 3 temperatures. Each point represents the mean of 10 seedlings.

$\mathrm{mm}$ in length, germinated seeds were transplanted 1-cm deep in pots that had been previously watered to field capacity.

\section{Temperature Experiment}

Five germinated seeds of each species were transplanted into the pots and were placed in controlled-environment growth chambers with alternate 12 -h day/night temperatures maintained at $10 / 5$, $15 / 5$, and $20 / 5^{\circ} \mathrm{C}$. Photosynthetic photon flux density was approximately 190 micro-Einsteins $\mathrm{m}^{-2} \mathrm{~s}^{-1}$, and daytime relative humidity ranged from 60 to $70 \%$. Seedlings were maintained near field capacity by watering the pots every 2 days with deionized water during the first 2 weeks of growth and with 0.25 strength Hoagland solution thereafter. Seedlings were thinned to 1 seedling per container when the main stem had 2 fully developed leaves.

Shoots and roots were harvested $10,17,24,31,38$, and 45 days after seedling emergence. Leaf and tiller development was evaluated using the system of Klepper et al. (1982), and root development was quantified using the method of Klepper et al. (1984). A more detailed discussion of how the root classification system of

Mention of a trademark, proprietary product, or vendor does not constitute guarantee or warranty of the products by the U.S. Department of Agriculture and Utah State University, and does not imply approval to the exclusion of other products or vendors that may also be suitable.
Klepper et al. (1984) was applied to seedlings of Hycrest, Whitmar, and cheatgrass is contained in Aguirre and Johnson (1991). Although the root classification system of Klepper et al. (1984) uses a naming system that identifies roots by their relationship to spccific nodes rather than designating roots as seminal or adventitious roots. In this paper we also indicate roots by these traditional names, although these names are subject to various definitions and misinterpretation, as discussed by Klepper et al. (1984). At each sampling date, root systems were washed free of soil and then dissected under a low magnification ( $\times 10$ to $\times 50)$ microscope to determine the relationship among leaves, tillers, and roots. Characteristics examined included: main stem Haun stage (Haun 1973), leaf area (Licor LI-3100 area meter ${ }^{1}$ ), length and order of branching of the primary root, length and order of branching of second group of seminal roots (roots associated with the epiblast node, node-1), number and order of branching of first group of adventitious roots (roots associated with the first foliar node, node 1), total root length (Comair root scanner'), and root and shoot dry weight (oven-dried at $60^{\circ} \mathrm{C}$ for $48 \mathrm{~h}$ ).

A split-plot experimental design was used with temperature regimes as main plots, species as subplots, and dates as sub-sub plots with 5 replications per treatment combination. Main effects 
Table 1. Influence of temperature on root and shoot developmental characteristics of Whitmar, Hycrest, and cheatgrass averaged across species and 6 harvests.

\begin{tabular}{|c|c|c|c|c|c|c|c|c|c|c|c|c|}
\hline Temperature & $\begin{array}{l}\text { Leaf } \\
\text { area }\end{array}$ & $\begin{array}{l}\text { Plant } \\
\text { height }\end{array}$ & $\begin{array}{l}\text { Main } \\
\text { stem } \\
\text { Haun }\end{array}$ & $\begin{array}{c}\text { Total } \\
\text { root } \\
\text { length }\end{array}$ & $\begin{array}{l}\text { Root: } \\
\text { total } \\
\text { dry } \\
\text { weight } \\
\text { ratio }\end{array}$ & $\begin{array}{c}\text { Primary } \\
\text { root } \\
\text { length }\end{array}$ & $\begin{array}{l}\text { Order of } \\
\text { branching } \\
\text { of } \\
\text { primary } \\
\text { root }\end{array}$ & $\begin{array}{c}\text { Seminal } \\
\text { roots }^{b}\end{array}$ & $\begin{array}{l}\text { Length } \\
\text { of } \\
\text { seminal } \\
\text { root } \\
\text { axes }^{b}\end{array}$ & $\begin{array}{l}\text { Order of } \\
\text { branching } \\
\text { of } \\
\text { seminal } \\
\text { roots }\end{array}$ & $\begin{array}{l}\text { Adven- } \\
\text { titious } \\
\text { roots }\end{array}$ & $\begin{array}{c}\text { Length of } \\
\text { adven- } \\
\text { titious } \\
\text { axes }^{c}\end{array}$ \\
\hline${ }^{\circ} \mathrm{C}$ & $\mathrm{cm}^{2}$ & cm & & $\mathrm{cm}$ & $\%$ & $\mathrm{~cm}$ & & no. & $\mathrm{cm}$ & & no. & $\mathrm{cm}$ \\
\hline $10 / 5$ & $0.6 a$ & $7.2 \mathrm{a}$ & $1.5 \mathrm{a}$ & $21.2 \mathrm{a}$ & $30.1 \mathrm{a}$ & $7.4 \mathrm{a}$ & $0.6 \mathrm{a}$ & $0.6 \mathrm{a}$ & $1.0 \mathrm{a}$ & $0.0 \mathrm{a}$ & $0.0 \mathrm{a}$ & $0.0 \mathrm{a}$ \\
\hline $15 / 5$ & $1.2 \mathrm{ab}$ & $9.0 \mathrm{~b}$ & $2.0 \mathrm{~b}$ & $43.0 \mathrm{~b}$ & $33.1 \mathrm{a}$ & $9.1 \mathrm{~b}$ & $0.8 \mathrm{~b}$ & $0.8 \mathrm{~b}$ & $2.7 \mathrm{~b}$ & $0.1 \mathrm{a}$ & $0.1 \mathrm{~b}$ & $0.2 b$ \\
\hline $20 / 5$ & $1.7 \mathrm{~b}$ & $11.3 \mathrm{c}$ & $2.3 \mathrm{c}$ & $59.3 \mathrm{c}$ & $31.8 \mathrm{a}$ & $9.6 \mathrm{~b}$ & $1.1 \mathrm{c}$ & $1.1 \mathrm{c}$ & $4.2 \mathrm{~b}$ & $0.2 b$ & $0.2 \mathrm{c}$ & $0.5 b$ \\
\hline
\end{tabular}

Means within columns followed by the same letter are not significantly $(P<0.05)$ different by LSD.

${ }^{b}$ Second group of seminal roots (roots associated with the epiblast node, node -1 ).

${ }^{c}$ Roots associated with the first foliar node (node 1).

and interactions were considered significant if $P<0.05$.

\section{Competition Experiment}

Monocultures of Hycrest or Whitmar were established by transplanting 1, 2, or 5 germinated seeds into pots with equal spacing, giving ratios of Hycrest to cheatgrass or Whitmar to cheatgrass of $1: 0,2: 0$, and 5:0, representing plant densities of 32, 64, and 159 plants $\mathrm{m}^{-2}$, respectively. Mixtures were established by transplanting 1 or 4 germinated seeds of cheatgrass into the pots containing
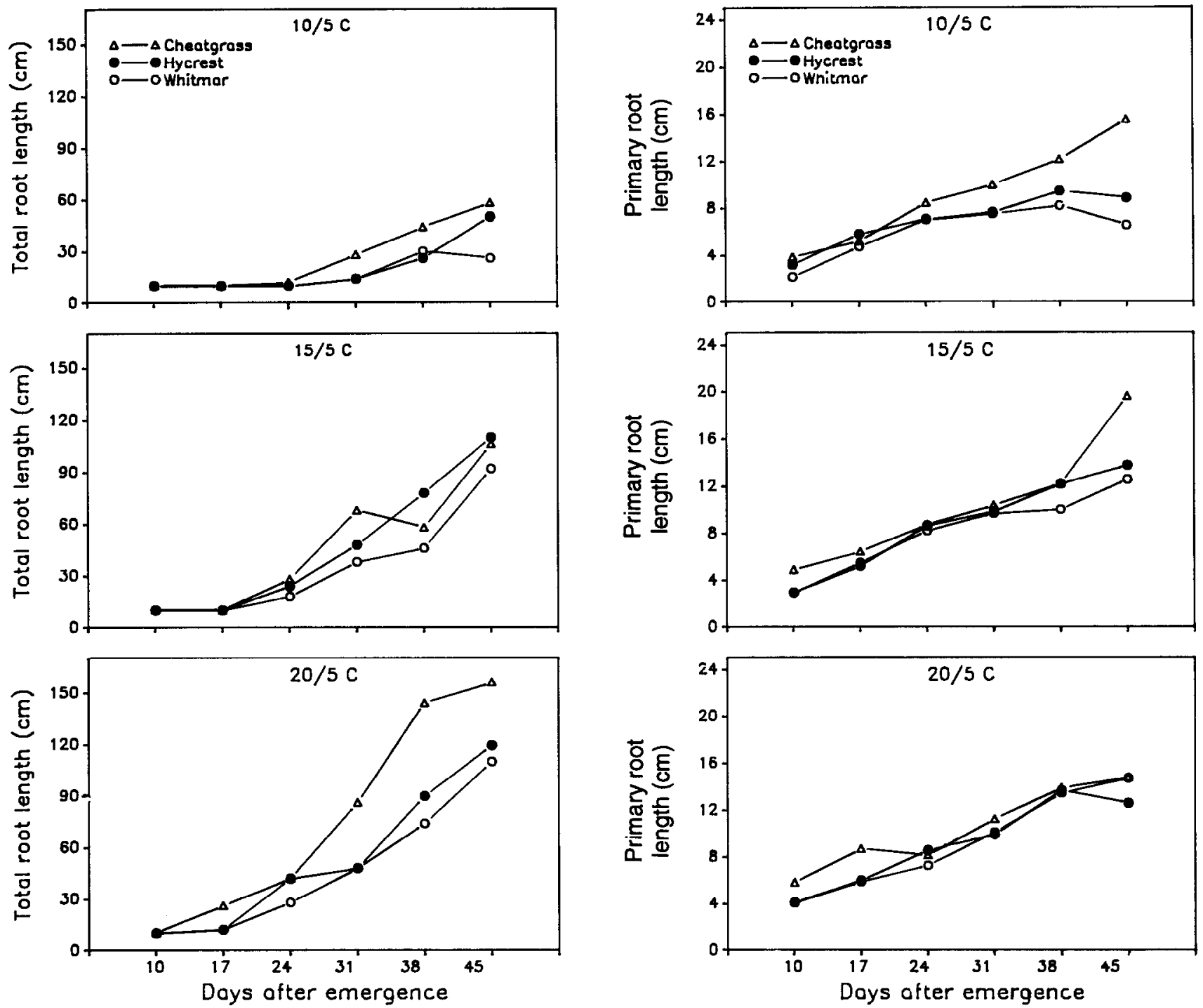

either 1 Hycrest seedling or 1 Whitmar seedling, resulting in wheatgrass:cheatgrass ratios of $1: 1$ and 1:4, respectively. This experiment was conducted in a greenhouse during October and November in 1988. No artificial lighting was provided, and air temperatures were maintained between 17 to $25^{\circ} \mathrm{C}$. Deionized water was used for irrigating the pots during the first 15 days after transplanting; thereafter, a 0.25 strength Hoagland solution was used.
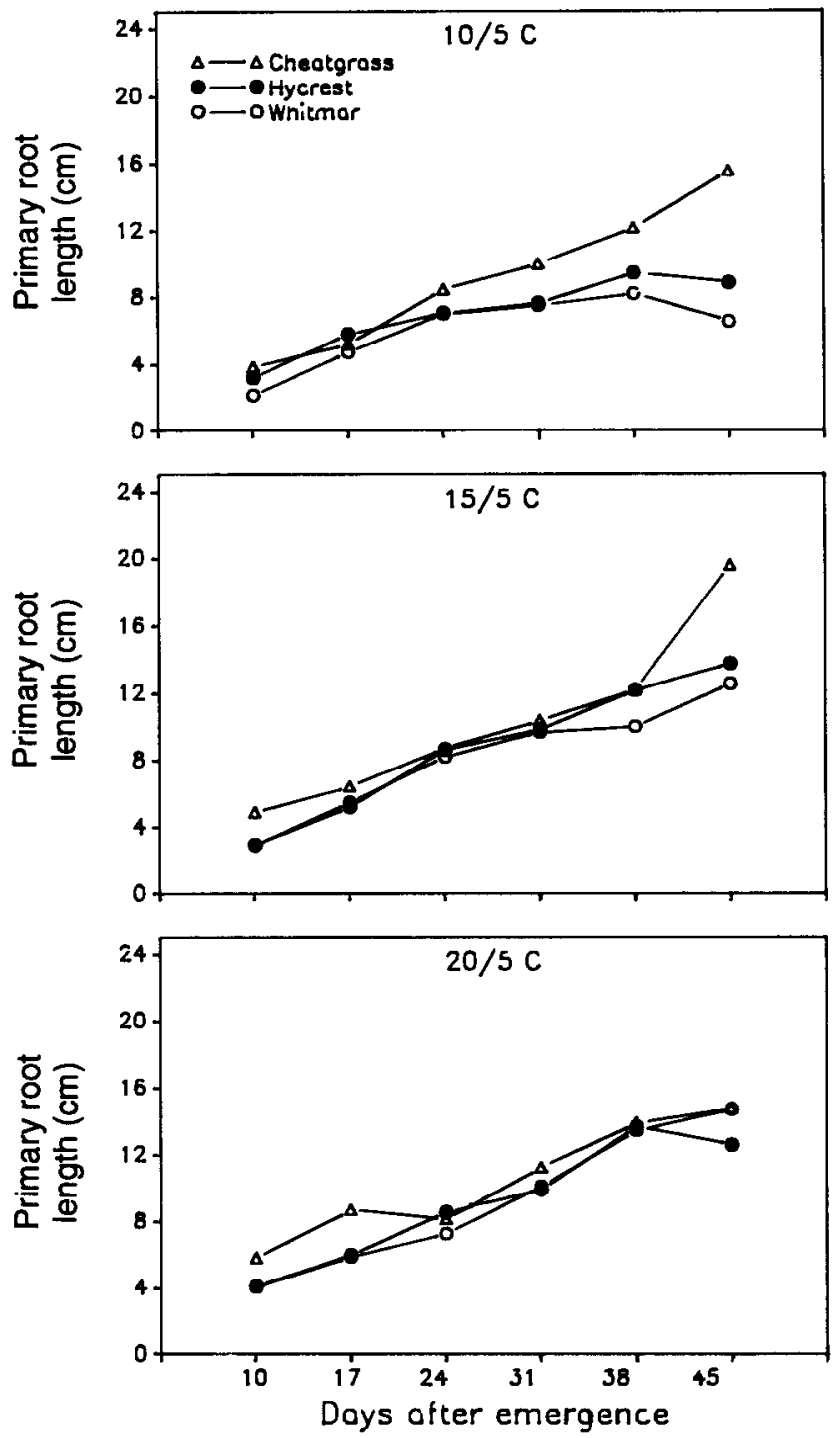

Fig. 2. Total root length $(S D=10.1)$ and primary root length $(S D=1.3)$ for cheatgrass, Hycrest, and Whitmar as a function of days after emergence at 3 temperatures. Each point represents the mean of 10 seedlings. 

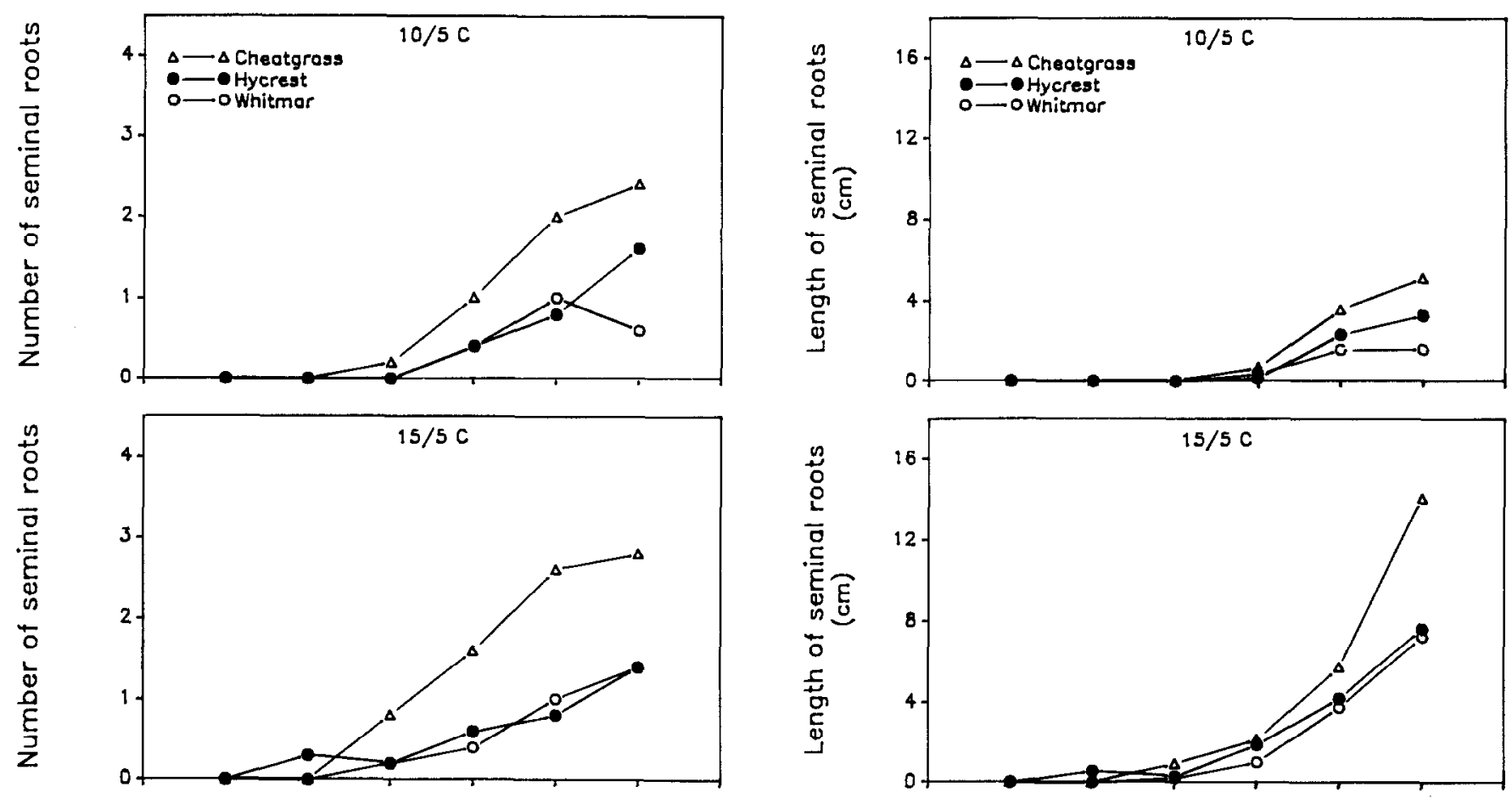

告
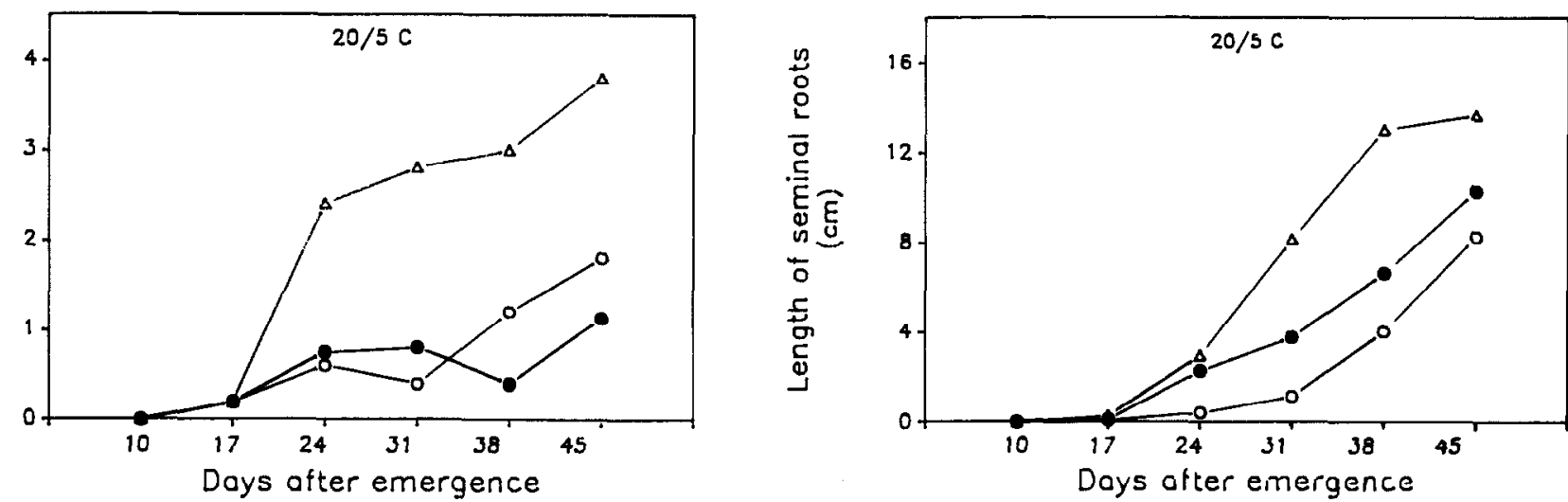

Fig. 3. Number of seminal roots (roots associated with the epibiast node, node -1$)(\mathrm{SD}=1.29)$ and length of seminal roots (SD $=1.3$ ) for cheatgrass, Hycrest, and Whitmar as a function of days after emergence at 3 temperatures. Each point represents the mean of 10 seedlings.

Seedlings were harvested at 15,30 , and 50 days after seedling emergence. Root and shoot characteristics were evaluated as above. Soil samples (18-cm deep) were obtained at the last harvest and oven-dried at $120^{\circ} \mathrm{C}$ for $48 \mathrm{hr}$, and soil water content was determined. The relationship between soil water content and soil water potential was obtained by mixing various amounts of water with dried soil, and then measuring soil water potential with screen-cage psychrometers.

A split-plot design with an incomplete factorial arrangement with 8 replications was used for the experiment. Analysis of variance and Least Square Difference (LSD) multiple comparison tests were used to identify significant differences among treatment means. Main effects and interactions were considered to be significant if $P<0.05$.

\section{Results}

\section{Temperature Experiment}

Temperature significantly affected all shoot and root parameters, except for the ratio of root to total dry weight (Table 1). Shoot and root growth increased with temperature. Whitmar and Hycrest had similar responses to temperature, which generally differed from the responses of cheatgrass (Table 2). Growth of cheatgrass seedlings was generally greater than that of Hycrest and Whitmar seedlings, but species did not differ in root to total dry weight ratio, order of branching of the primary root, and number and length of adventitious roots (roots associated with the first foliar node, node 1).

Although there was no significant temperature $\times$ species $X$ harvest date interaction, cheatgrass seedlings generally developed faster than Hycrest and Whitmar seedlings, regardless of temperature and harvest date. Leaf development and leaf area (Fig. 1) as well as total root length (Fig. 2) of cheatgrass generally exceeded those of Hycrest and Whitmar, particularly at harvests beyond 24 days after emergence. However, root lengths of cheatgrass and Hycrest were similar at $15 / 5^{\circ} \mathrm{C}$ (Fig. 2). The primary root of cheatgrass was longer than that of Hycrest and Whitmar at $10 / 5^{\circ}$ $\mathrm{C}$; however, primary root lengths of the 3 grasses were similar at $15 / 5$ and $20 / 5^{\circ} \mathrm{C}$ (Fig. 2). The primary root of cheatgrass branched first followed by Hycrest and Whitmar (data not shown). Cheatgrass had a greater number (after 24 days) and length (after 38 days) of second group of seminal roots (those associated with the epiblast node, node -1) than Hycrest and Whitmar seedlings at all 3 temperatures (Fig. 3).

Leaf development was similar in Hycrest and Whitmar (Fig. 1), 
Table 2. Root and shoot development characteristics for Whitmar, Hycrest, and cheatgrass averaged across 3 temperatures and 6 harvests.

\begin{tabular}{|c|c|c|c|c|c|c|c|c|c|c|c|c|}
\hline Species & $\begin{array}{l}\text { Leaf } \\
\text { area }\end{array}$ & $\begin{array}{c}\text { Plant } \\
\text { height }\end{array}$ & $\begin{array}{l}\text { Main } \\
\text { stem } \\
\text { Haun }\end{array}$ & $\begin{array}{c}\text { Total } \\
\text { root } \\
\text { length }\end{array}$ & $\begin{array}{c}\text { Root: } \\
\text { total } \\
\text { dry } \\
\text { weight } \\
\text { ratio }\end{array}$ & $\begin{array}{c}\text { Primary } \\
\text { root } \\
\text { length }\end{array}$ & $\begin{array}{l}\text { Order of } \\
\text { branching } \\
\text { of } \\
\text { primary } \\
\text { root }\end{array}$ & $\begin{array}{l}\text { Seminal } \\
\text { roots }^{b}\end{array}$ & $\begin{array}{l}\text { Length } \\
\text { of } \\
\text { seminal } \\
\text { root } \\
\text { axes }^{\text {b }}\end{array}$ & $\begin{array}{c}\text { Order of } \\
\text { branching } \\
\text { of } \\
\text { seminal } \\
\text { roots }^{\mathrm{b}}\end{array}$ & $\begin{array}{l}\text { Adven- } \\
\text { titious } \\
\text { roots }^{c}\end{array}$ & $\begin{array}{l}\text { Length of } \\
\text { adven- } \\
\text { titious } \\
\text { axes }\end{array}$ \\
\hline Whitmar & $\begin{array}{c}\mathrm{cm}^{2} \\
0.5 \mathrm{a}\end{array}$ & $\begin{array}{l}\mathrm{cm} \\
9.2 \mathrm{a}\end{array}$ & $1.8 \mathrm{a}$ & $\begin{array}{c}\mathrm{cm} \\
3.1 \mathrm{a}\end{array}$ & $\begin{array}{c}\% \\
35.7 \mathrm{a}\end{array}$ & $\begin{array}{l}\mathrm{cm} \\
7.8 \mathrm{a}\end{array}$ & $0.7 \mathrm{a}$ & $\begin{array}{l}\text { no. } \\
0.5 a\end{array}$ & $\begin{array}{c}\mathrm{cm} \\
1.6 \mathrm{a}\end{array}$ & $0.0 \mathrm{a}$ & $\begin{array}{l}\text { no. } \\
0.0 \mathrm{a}\end{array}$ & $\begin{array}{c}\mathrm{cm} \\
0.0 \mathrm{a}\end{array}$ \\
\hline Hycrest & $\begin{array}{l}0.3 a \\
1.1 a b\end{array}$ & $\begin{array}{r}9.2 \mathrm{a} \\
10.9 \mathrm{a}\end{array}$ & $\begin{array}{l}1.0 \mathrm{a} \\
1.8 \mathrm{a}\end{array}$ & $40.1 a b$ & $28.5 a$ & $8.3 \mathrm{a}$ & $0.8 \mathrm{a}$ & $0.5 \mathrm{a}$ & $2.4 a$ & $0.1 a$ & $0.1 \mathrm{a}$ & $0.3 a$ \\
\hline Cheatgrass & $1.9 b$ & $7.4 \mathrm{~b}$ & $2.2 \mathrm{~b}$ & $50.3 \mathrm{~b}$ & $30.9 a$ & $10.0 \mathrm{~b}$ & $0.9 a$ & $1.4 \mathrm{~b}$ & $3.9 \mathrm{~b}$ & $0.2 b$ & $0.2 \mathrm{a}$ & $0.4 a$ \\
\hline
\end{tabular}

"Means within a column followed by the same letter are not significantly $(P<0.05)$ different by LSD.

Second group of seminal roots (roots associated with the epiblast node, node -1 ).

'Roots associated with the first foliar node (node 1).

although leaf area (Fig. 1), total root length and primary root length (Fig. 2), and number and length of seminal roots associated with the epiblast node (Fig. 3) were greater in Hycrest than Whitmar as days after emergence increased. Whitmar allocated a larger proportion of carbon to roots than Hycrest and cheatgrass beyond $31 \mathrm{~d}$ after emergence at all 3 temperatures (data not shown). Cheatgrass elongated adventitious roots earlier and at colder temperatures $\left(10 / 5^{\circ} \mathrm{C}\right)$ than Hycrest, and Whitmar did not elongate
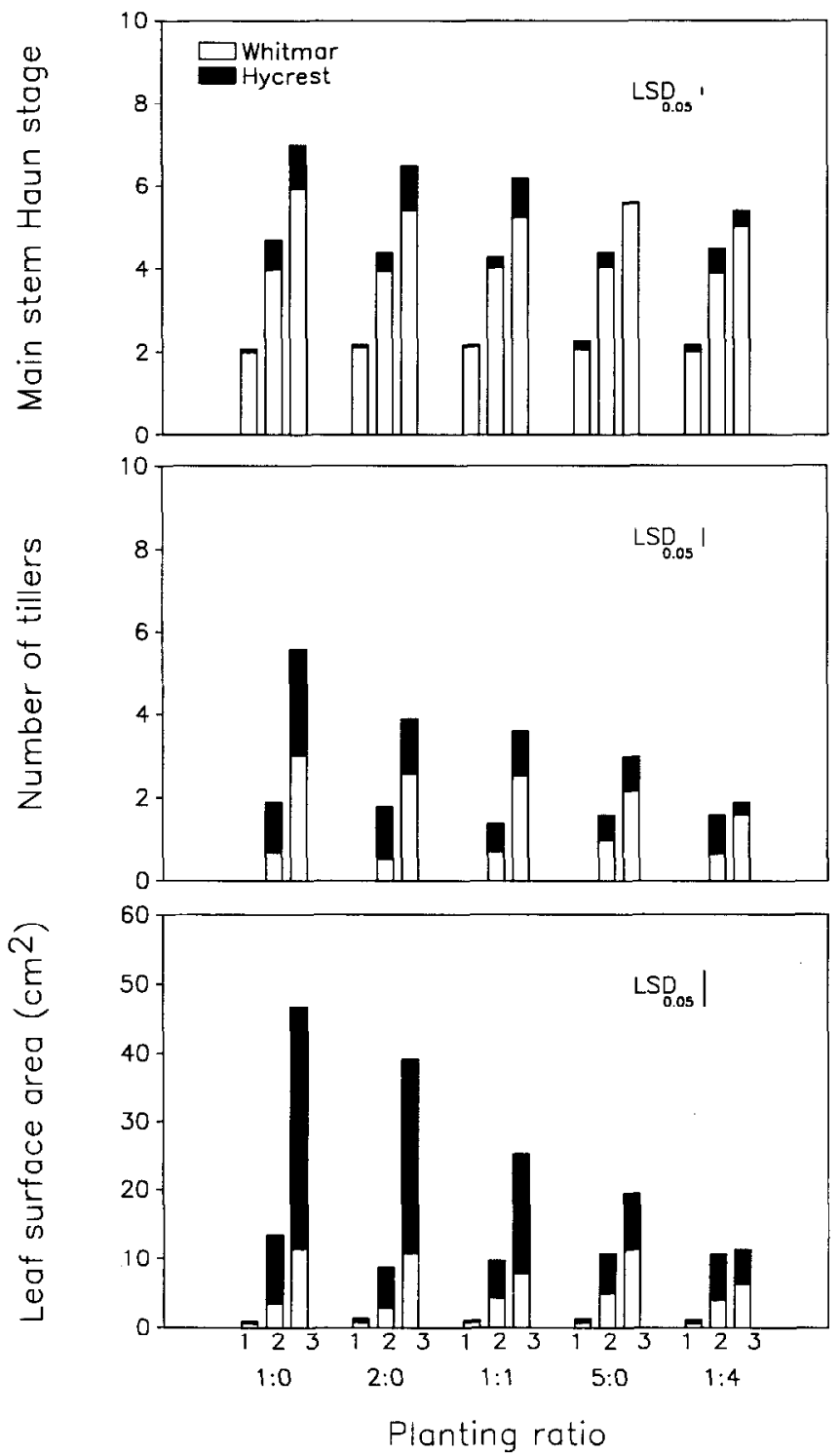

Fig. 4. Seedling root and shoot characteristics for Hycrest and Whitmar seedlings grown at various planting ratios in monocultures (1:0, 2:0, and 5:0) and mixtures with cheatgrass (1:1 and 1:4). Harvests 1, 2, and 3 were obtained at 15, 30, and 50 days after seedling emergence, respectively. Each bar represents the mean of 8 values. adventitious roots at any temperature (data not shown).

\section{Competition Experiment}

Generally, the main effects of planting ratio, species, and harvest dates were significant for all seedling characteristics. The 3-way (treatment $X$ species $X$ harvest dates) and 2-way (treatment $X$ species) interactions were not significant for length and order of branching of the primary root, order of branching of the second group of seminal roots, number of roots from the first foliar node,
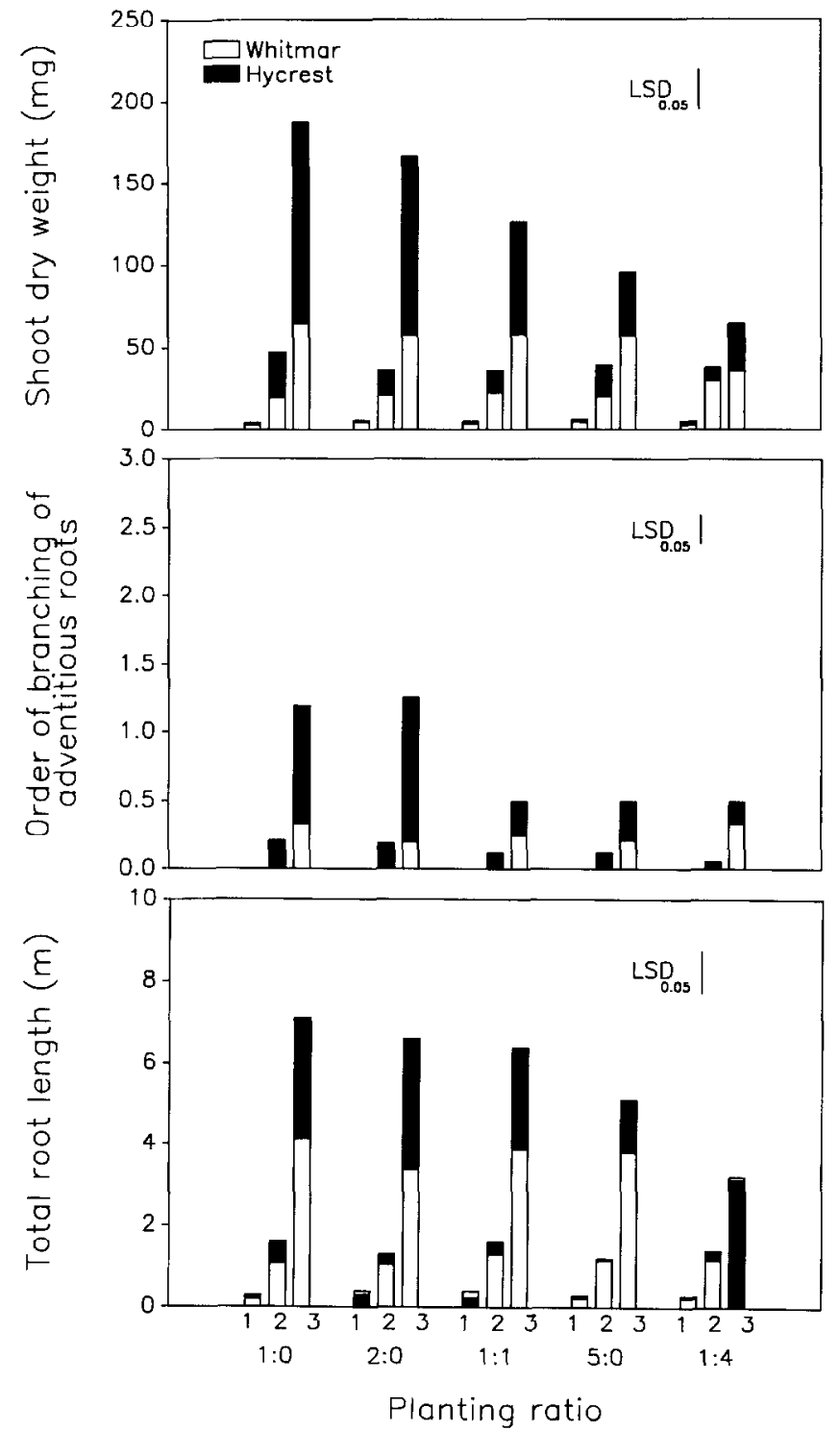
Table 3. Mean length and order of branching (OB) of the primary root, order of branching of the second group of seminal roots (node -1 ), number of roots associated with the first foliar node (node 1), and root dry weight for Hycrest and Whitmar in the competition experiment.

\begin{tabular}{|c|c|c|c|c|c|}
\hline \multirow[b]{2}{*}{ Species } & \multicolumn{2}{|c|}{ Primary root } & \multirow{2}{*}{$\begin{array}{c}\text { OB of } \\
\text { seminal } \\
\text { roots } \\
\text { (node }-1)\end{array}$} & \multirow{2}{*}{$\begin{array}{l}\text { Adventi- } \\
\text { titious } \\
\text { roots } \\
\text { (node 1) }\end{array}$} & \multirow{2}{*}{$\begin{array}{c}\text { Root } \\
\text { dry } \\
\text { weight }\end{array}$} \\
\hline & length & OB & & & \\
\hline $\begin{array}{l}\text { Hycrest } \\
\text { Whitmar }\end{array}$ & $\begin{array}{c}\mathrm{cm} \\
14.8 \mathrm{a} \\
16.0 \mathrm{~b}\end{array}$ & $\begin{array}{l}1.6 \mathrm{a} \\
1.4 \mathrm{~b}\end{array}$ & $\begin{array}{l}0.8 \mathrm{a} \\
0.5 \mathrm{~b}\end{array}$ & $\begin{array}{l}\text { no. } \\
1.6 \mathrm{a} \\
1.1 \mathrm{~b}\end{array}$ & $\begin{array}{c}\mathrm{mg} \\
19.6 \mathrm{a} \\
11.5 \mathrm{~b}\end{array}$ \\
\hline
\end{tabular}

"Means within the same column followed by the same letter are not significantly $(P<0.05)$ different by LSD.

and root dry weight. Consequently, only species means will be considered for these 5 characteristics (Table 3). Hycrest seedlings had greater order of branching of the primary root, order of branching of the second group of seminal roots, number of adventitious roots (roots associated with the first foliar node), and root dry weight than Whitmar, whether they were growing in monocultures or in mixtures with cheatgrass.

Significant 3-way (treatment $\times$ species $\times$ harvest date) and 2-way (treatment $X$ species) interactions were observed for main stem Haun stage, number of tillers, leaf area, shoot dry weight, total root length, and order of branching of roots associated with the first foliar node. Except for order of branching of roots associated with the first foliar node, root and shoot characteristics did not differ among the planting ratios until $\mathbf{5 0}$ days after seedling emergence (Fig. 4). At $\mathbf{5 0}$ days after emergence, seedlings growing in the 1:0 planting ratio (Hycrest:cheatgrass) had the highest main stem Haun stage, whereas leaf development was the lowest for the 1:4 planting mixture (Fig. 4). Hycrest seedlings did not differ in leaf development between monoculture or mixture plantings when grown at the same planting densities, such as between 1:4 and 5:0 planting ratios (159 plants $\mathrm{m}^{-2}$ ) and between $1: 1$ and $2: 0$ planting ratios $\left(64\right.$ plants $\left.\mathrm{m}^{-2}\right)$. Whitmar seedlings had greater leaf development when grown at planting ratios of 1:0 (Whitmar:cheatgrass) than when grown at ratios of $1: 1$ and $1: 4$ at 50 days after seedling emergence. Whitmar seedlings had a lower main stem Haun stage when grown at a 1:4 than a 5:0 planting ratio.

At $\mathbf{5 0}$ days after seedling emergence, Hycrest seedlings grown at a 1:4 ratio had fewer tillers than those grown at a 5:0 ratio (Fig. 4). Hycrest seedlings grown at a $1: 1$ planting ratio had fewer tillers than those grown at a 2:0 ratio. Whitmar seedlings grown at a 1:4 planting ratio (Whitmar:cheatgrass) had fewer tillers than seedlings grown at 5:0, 1:1, 2:0, and $1: 0$ ratios at 50 days after seedling emergence.

At 50 days after seedling emergence, Hycrest seedlings grown at a 1:4 planting ratio (Hycrest:cheatgrass) had a smaller leaf area than seedlings grown at a 5:0 planting ratio (Fig. 4). At the 1:1 planting ratio Hycrest seedlings had a smaller leaf area than seedlings grown at a 2:0 and 1:0 planting ratio. Whitmar seedlings grown at a 1:4 planting ratio had a smaller leaf area than those grown at 5:0, 1:1, 2:0, and $1: 0$ planting ratios at 50 days after seedling emergence.

At $\mathbf{5 0}$ days after seedling emergence, shoot weights were lower for Hycrest seedlings grown at a 1:4 planting ratio (Hycrest:cheatgrass) than those grown at a 5:0 planting ratio (Fig. 4). Shoot dry weights were lower for Hycrest seedlings grown at a $1: 1$ planting ratio than those grown at a 2:0 and 1:0 planting ratio. Whitmar seedlings had a lower shoot dry weight when grown at a 1:4 ratio (Whitmar:cheatgrass) than those grown at 5:0, 1:1, 2:0, and 1:0 planting ratios.

Hycrest seedlings grown at a 1:4 planting ratio (Hycrest:cheatgrass) had less branching development of adventitious roots than those grown at 5:0,1:1,2:0, and 1:0 planting ratios at 30 days after

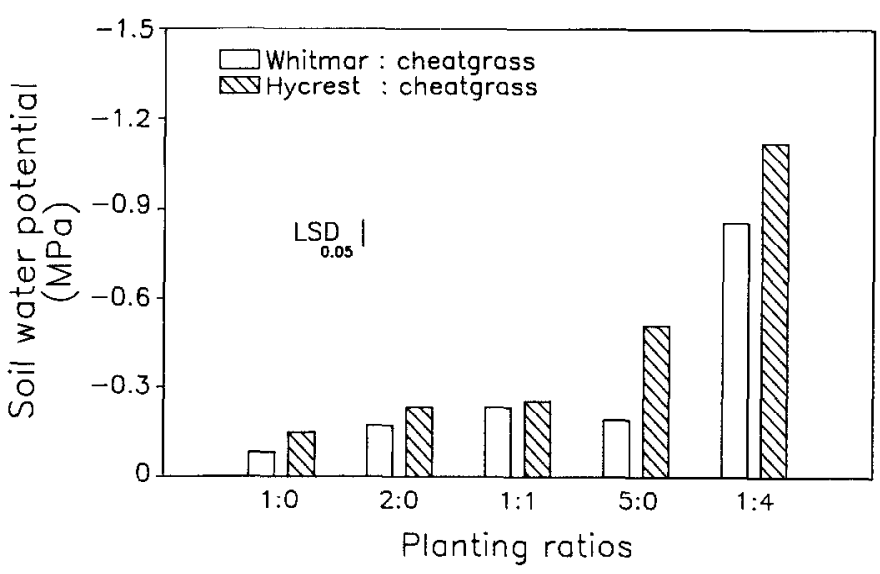

Fig. 5. Soll water potential (MPa) for Whitmar and Hycrest at $\mathbf{5 0}$ days after seedling emergence grown in monocultures $(1: 0,2: 0$, and $5: 0 ; 32,64$, and 159 plants $\mathrm{m}^{-2}$, respectively) and in mixtures with chentgrass (1:1 and 1:4). Each bar represents the mean of 8 values.

emergence (Fig. 4). At 50 days after seedling emergence, Hycrest seedlings grown at a 1:4 and 5:0 planting ratio did not differ in order of branching; however, seedlings grown at a 1:1 planting ratio were less branched than those grown at planting ratios of 2:0 or 1:0. For Whitmar, order of branching did not vary during the study.

At $\mathbf{5 0}$ days after seedling emergence, Hycrest seedlings grown at a. 1:4 planting ratio (Hycrest:cheatgrass) had a smaller total root length than those grown at a 5:0, 1:1, 2:0, and 1:0 planting ratio (Fig. 4). For Whitmar, total root length did not differ among the planting ratios at any of the harvest dates. Soil water was depleted to a greater extent in treatments with cheatgrass (1:1 and 1:4 planting ratios) compared with monoculture treatments (2:0 and 5:0 planting ratios, respectively) (Fig. 5). Hycrest-cheatgrass planting mixtures depleted soil moisture to lower soil water potentials than Whitmar-cheatgrass mixtures.

\section{Discussion}

\section{Temperature}

Rapid germination and seedling growth at low temperature is critical for successful establishment in arid or semiarid environments (Plummer 1943). Rapid root penetration under these conditions is essential if bluebunch and crested wheatgrasses are to become established in areas where cheatgrass is abundant (DeWitt 1969). Shoot growth rates of forage grasses typically decrease as temperatures decline. For example, McWilliam et al. (1970) found that growth rate declined as temperature decreased from 24/19 to $15 / 10^{\circ} \mathrm{C}$ for tall fescue (Festuca arundinacea Schreber) and Italian ryegrass (Lolium multiflorum Lam.) (McWilliam et al. 1970). Ellern and Tadmor (1966) also observed that temperatures in the range of 4 to $10^{\circ} \mathrm{C}$ delayed germination and early seedling growth in several range plants, including crested wheatgrass. Hsu et al. (1985) reported that seedling growth of perennial warm-season grasses was reduced considerably at $20^{\circ} \mathrm{C}$, compared with growth at 25 and $30^{\circ} \mathrm{C}$. In the present study, the seedling growth of cheatgrass, Hycrest, and Whitmar declined as temperature decreased. Seedling growth for all 3 species decreased markedly at $10 / 5^{\circ} \mathrm{C}$ compared with the $15 / 5$ and $20 / 5^{\circ} \mathrm{C}$ temperatures.

Rates of leaf expansion and frequency of leaf appearance were greatly influenced by temperature in perennial ryegrass (Lolium perenne L.) and orchardgrass (Dactylis glomerata L.) (Cooper 1964). Peacock (1976) reported that leaf extension rates of coolseason grasses increased as the temperature of the stem apex increased from 9 to $16^{\circ} \mathrm{C}$. In addition, Hsu et al. (1985) observed 
that seedlings of annual warm-season grasses developed faster than warm-season perennial species, regardless of temperature. In the present study, cheatgrass had greater leaf development and leaf area production than Hycrest and Whitmar, although differences were small at the $10 / 5^{\circ} \mathrm{C}$ treatment.

Extension and development of seminal roots are extremely important in seedling establishment, although plant establishment depends ultimately on the extension of adventitious roots (Esau 1960). The longevity of seedlings restricted to seminal roots might be critical to seedling success where the soil profile remains exposed to low temperatures. Van Der Sluijs and Hyder (1974) reported that seminal primary roots of blue grama seedlings grew actively in the greenhouse for 22 weeks when restricted only to seminal roots. In the present study, adventitious roots did not elongate in Whitmar seedlings so that seedling growth was supported entirely by seminal roots during the $45 \mathrm{~d}$ of the study.

Harris (1977) reported that rapid elongation of primary roots combined with well-developed adventitious roots enabled cheatgrass to exploit a greater volume of soil, allowing cheatgrass to outcompete bluebunch wheatgrass. Wilson and Briske (1979) observed that if adventitious rooting in blue grama seedlings was not initiated, blue grama seedlings died during winter. They also found that blue grama seedlings required temperatures between 15 and $30^{\circ} \mathrm{C}$ for elongation of adventitious roots. In the present study, cheatgrass initiated adventitious roots earlier and at colder temperatures $\left(10 / 5^{\circ} \mathrm{C}\right)$ than either Hycrest and Whitmar. Adventitious roots are extremely important for seedling establishment because they eventually replace the seminal roots. Seminal roots can only provide short-term support to the young seedling because the vascular system connects tillers with adventitious roots but not with the seminal roots (Esau 1960). The earlier elongation of adventitious roots in cheatgrass and the absence of adventitious roots in Whitmar would favor establishment of cheatgrass, particularly at low temperatures.

Svejcar (1990) compared accumulated root length, leaf area, and biomass of cheatgrass and Agropyron desertorum under wellwatered conditions at $28 / 4^{\circ} \mathrm{C}$ day/night temperatures in a greenhouse. He found that cheatgrass was more efficient (per unit of biomass) in producing leaf area and root length than $A$. desertorum and suggested that this difference in efficiency was probably one of the factors contributing to the competitive advantage of cheatgrass seedlings compared to seedlings of perennial bunchgrasses. Svejcar (1990) expressed root/shoot relationships in terms of root length per unit leaf area and found values ranging from about 40 to $160 \mathrm{~cm} \mathrm{~cm}^{-2}$ for cheatgrass and $A$. desertorum. Calculating these ratios from data in Table 2, values were 6,36 , and 26 $\mathrm{cm} \mathrm{cm}^{-2}$ for Whitmar, Hycrest, and cheatgrass, respectively. This suggests that Hycrest would have the greatest ability to produce root length per unit leaf area followed by cheatgrass and Whitmar. Our ratios were probably lower than those of Svejcar (1990) because of the earlier, more frequent harvests in our study. Although Hycrest had the greatest ratios in our study, absolute root and shoot growth was still the greatest for cheatgrass.

Further studies should be conducted to elucidate the role of seminal roots and their longevity in bluebunch wheatgrass at low temperature regimes to better understand their influence on seedling establishment. Understanding seedling ability to elongate adventitious roots at low temperatures could help in selecting competive cultivars of bluebunch wheatgrass for rangeland seedings.

\section{Competition}

Previous research has also shown that shoot growth of crested and bluebunch wheatgrass were reduced when growing in mixtures with cheatgrass. Romo and Eddleman (1987) observed that without competition seedlings of bluebunch wheatgrass, Junegrass [Koeleria cristata (L.) Pers.], and squirreltail [Sitanion hystrix
(Nutt.) J.G. Smith) produced more tillers and leaves than those grown with competition from Japanese brome (Bromus japonicus Thumb. ex Murray) at $50,100,200$, and 400 plants $\mathrm{m}^{-2}$. Rummel (1946) and Hull (1963) found that increasing cheatgrass densities reduced crested wheatgrass shoot weight. Similarly, Harris (1967) reported that forage yield of bluebunch wheatgrass was reduced as density of cheatgrass increased. However, Buman et al. (1988) grew Hycrest crested wheatgrass in a 1:1 planting ratio with cheatgrass and found that these 2 grasses had similar leaf areas and shoot dry weight.

Root dry weight (Rummel 1946) and root growth (Hull 1963) in crested wheatgrass decreased as density of cheatgrass increased. Harris (1967) observed that depth of root penetration of bluebunch wheatgrass seedlings was reduced as density of cheatgrass increased. Buman et al. (1988) observed that Hycrest and cheatgrass had similar maximum root lengths and root dry weights when grown in a 1:1 planting ratio. Although long-term survival was not evaluated in the present study, seedling survival would ultimately be influenced by reduced root growth. Seedling survival and establishment of crested wheatgrass (Rummel 1946) and bluebunch wheatgrass (Nelson et al. 1970, Harris 1967) were reduced by cheatgrass competition. Romo and Eddleman (1987) observed that survival of seedlings of bluebunch wheatgrass was not reduced by Japanese brome competition; however, survival of squirreltail seedlings was greater when grown without competition.

Little information is available on the effect of competition on root pattern development. The present study indicated that order of branching of the primary root, ordering of branching of the second group of seminal roots, and number of adventitious roots associated with the first foliar node were not affected in either Hycrest or Whitmar when they were grown with cheatgrass. However, branching of adventitious roots associated with the first foliar node was reduced to a greater extent when grown in mixtures with cheatgrass (1:1 and 1:4 planting ratios, 64 and 159 seedlings $\mathrm{m}^{-2}$, respectively). Order of branching of adventitious roots is a characteristic that probably greatly influences total root surface of the mature plant. Consequently, a reduced order of branching of adventitious roots may decrease a plant's ability to extract both water and nutrients.

Hycrest seedlings grown in competition with cheatgrass at planting ratios of $1: 1$ and $1: 4$ had reductions in leaf area of 46 and $76 \%$, while Whitmar only showed reductions of 31 and $50 \%$ for the same densities, respectively. Similarly, total root length for Hycrest was reduced 10 and $56 \%$ for the same plant densities, respectively, while total root length for Whitmar declined only 20 and $22 \%$, respectively. Although Hycrest had a large percentage reduction for most seedling characteristics when competing with cheatgrass, Hycrest had greater absolute growth than Whitmar. Because seedlings of Hycrest maintain greater growth than seedlings of Whitmar, Hycrest seedlings would occupy a larger soil volume and aerial space than Whitmar seedlings. Consequently, seedlings of Hycrest would compete earlier and more effectively than Whitmar seedlings.

The reduced growth for Whitmar seedlings resulted in significantly higher soil water potentials for Whitmar than Hycrest treatments. This lowered soil water acquisition by Whitmar seedlings would result in greater soil water available for cheatgrass growth. This coupled with greater root growth rates for mature plants of $A$. desertorum compared with $P$. spicata (Eissenstat and Caldwell 1987) and the large stature of mature plants of Hycrest (Asay et al. 1985) suggest that Hycrest would be a more effective competitor with cheatgrass than Whitmar.

\section{Literature Cited}

Aguirre, L., and D.A. Johnson. 1991. Root morphological development in relation to shoot growth in seedlings of four range grasses. J. Range Manage. 44:341-346. 
Asay, K.H., D.R. Dewey, F.B. Gomm, D.A. Johnson, and J.R. Carlson. 1985. Registration of 'Hycrest' crested wheatgrass. Crop Sci. 25:368-369.

Barber, S.A. 1984. Soil nutrient availability. A mechanistic approach. John Wiley and Sons, Inc., New York.

Buman, R.A., and R.H. Abemethy. 1988. Temperature requirements for mountain rye, 'Hycrest'crested wheatgrass, and downy brome germination. J. Range Manage. 41:35-39.

Buman, R.A., S.B. Monsen, and R.H. Abernethy. 1988. Seedling competition between mountain rye, 'Hycrest' crested wheatgrass, and downy brome. J. Range Manage. 41:30-34.

Caldwell, M.M., J.H. Richards, D.A. Johnson, R.S. Nowak, and R.S. Dzurec. 1981. Coping with herbivory: photosynthetic capacity and resource allocation in two semiarid Agropyron bunchgrasses. Oecologia 50:14-24.

Clarkson, D.T. 1985. Factors affecting mineral nutrient acquisition by plants. Annu. Rev. Plant Physiol. 36:77-115.

Cooper, J.P. 1964. Climatic variation in forage grasses. I. Leaf development in climatic races of Lolium and Dactylis. J. Appl. Ecol. 1:45-61.

Daubenmire, R. 1942. An ecological study of the vegetation of southeastern Washington and adjacent Idaho. Ecol. Monogr. 12:53-79.

DeWitt, P.F. 1969. Environmental response to low temperature in Agropyron spicatum collected from native stands in western North America. M.S. Thesis, Washington State Univ., Pullman.

Eissenstat, D.M., and M.M. Caldwell. 1987. Characteristics of successful competitiors: an evaluation of potential growth rate in two cold desert tussock grasses. Oecologia 71:167-173.

Ellern, S.J., and N.H. Tadmor. 1966. Germination of range plant seeds at fixed temperatures. J. Range Manage. 19:341-345.

Ellern, S.J., and N.H. Tadmor. 1967. Germination of range seeds at alternating temperatures. J. Range Manage. 20:72-77.

Esau, K. 1960. Anatomy of seed plants. John Wiley and Sons, Inc., New York.

Evans, R.A., H.R. Holbo, R.E. Eckert, Jr., and J.A. Young. 1970. Functional environment of downy brome communities in relation to weed control and revegetation. Weed Sci. 18:154-162.

Harris, G.A. 1967. Some competitive relationships between Agropyron spicatum and Bromus tectorum. Ecol. Monogr. 37:89-111.

Harris, G.A. 1977. Root phenology as a factor of competition among grass seedlings. J. Range Manage. 30:172-177.

Haun, J.R. 1973. Visual quantification of wheat development. Agron. J. 65:116-119.

Hsu, F.H., C.J. Nelson, and A.G. Matches. 1985. Temperature effects on seedling development of perennial warm-season forage grasses. Crop Sci. 25:249-255.

Hull, A.C. 1963. Competition and water requirements of cheatgrass and wheatgrasses in the greenhouse. J. Range Manage. 16:199-204.

Johnson, D.A., and L. Aguirre. 1991. Effect of water on morphological development in seedlings of three range grasses: Root branching patterns. J. Range Manage. 44:355-360.
Keller, W., and A.T. Bleak. 1969. Root and shoot growth following preplanting treatment of grass seed. J. Range Manage. 22:43-46.

King, J. 1971. Competition between established and newly sown grass species. J. Brit. Grassl. Soc. 26:221-229.

Klepper, B., R.K. Belford, and R.W. Rickman. 1984. Root and shoot development in winter wheat. Agron. J. 76:117-122.

Klepper, B., R.W. Rickman, and C.M. Peterson. 1982. Quantitative characterization of vegetative development in small cereal grains. Agron. J. 74:789-792.

Klomp, G.J., and A.C. Hull, Jr. 1972. Methods for seeding three perennial wheatgrasses on cheatgrass ranges in southern Idaho. J. Range Manage. 25:266-268.

McWilliam, J.R., R.J. Clements, and P.M. Dowling. 1970. Some factors influencing the germination and early seedling development of pasture plants. Aust. J. Agr. Res. 21:19-32.

Nelson, J.R., A.M. Wilson, and C.J. Goebel. 1970. Factors influencing broadcast seeding in bunchgrass range. J. Range Manage. 23:163-170.

Peacock, J.M. 1976. Temperature and leaf growth in four grass species. J. Appl. Ecol. 13:225-232.

Plummer, A.P. 1943. The germination and early seedling development of twelve range grasses. Amer. Soc. Agron. J. 35:19-34.

Romo, J.T., and L.E. Eddleman. 1987. Effects of Japanese brome on growth of bluebunch wheatgrass, Junegrass and squirreltail seedlings. Reclam. and Reveg. Res. 6:207-218.

Kosenquist, U.W., and D.H. Gates. 1961. Responses of four grasses at different stages of growth to various temperature regimes. J. Range Manage. 14:198-202.

Rummel, R.S. 1946. Some effects of competition from cheatgrass brome on crested wheatgrass and bluestem wheatgrass. Ecology 27:159-167.

Snaydon, R.W., and C.D. Howe. 1986. Root and shoot competition between established ryegrass and invading grass seedlings. J. Appl. Ecol. 23:667-674.

Svejcar, T. 1990. Root length, leaf area, and biomass of crested wheatgrass and cheatgrass seedlings. J. Range Manage. 43:446-448.

Thill, D.C., R.D. Schirman, and A.P. Appleby. 1979. Influence of soil moisture, temperature, and compaction on the germination and emergence of downy brome (Bromus tectorum). Weed Sci. 27:625-630.

Tillman, D. 1982. Resource competition and community structure. Princeton Univ. Press, Princeton, N.J.

Van Der Sluijs, D.H., and D.N. Hyder. 1974. Growth and longevity of blue grama seedlings restricted to seminal roots. J. Range Manage. 27:117-119.

Wilson, A.M., and D.D. Briske. 1979. Seminal and adventitious root growth of blue grama seedlings on the Central Plains. J. Range Manage. 32:209-213.

Wilson, A.M., D.E. Wondercheck, and C.J. Goebel. 1974. Responses of range grass seeds to winter environments. J. Range Manage. 27:120-122.

Young, J.A., R.A. Evans, R.E. Eckert, Jr., and B.L. Kay. 1987. Cheatgrass. Rangelands 9:266-270. 